\title{
In vitro anticancer effects of two novel phenanthroindolizidine alkaloid compounds on human colon and liver cancer cells
}

\author{
JINGJING LIU ${ }^{1}$, YU HE ${ }^{1}$, DAN ZHANG ${ }^{1}$, YING CAI $^{1}$, CHENGGANG ZHANG $^{2}$, \\ PENG ZHANG ${ }^{3}$, HONGXIA ZHU ${ }^{4}$, NINGZHI XU ${ }^{1,4}$ and SHUFANG LIANG ${ }^{1}$ \\ ${ }^{1}$ Cancer Center, West China Hospital, Sichuan University and Collaborative Innovation Center for Biotherapy, \\ Chengdu, Sichuan 610041 ; $^{2}$ Department of Chemistry and Materials, Sichuan Normal University, Chengdu, \\ Sichuan 610066; ${ }^{3}$ Department of Urinary Surgery, West China Hospital, West China Medical School, \\ Sichuan University, Chengdu, Sichuan 610041; ${ }^{4}$ Laboratory of Cell and Molecular Biology and \\ State Key Laboratory of Molecular Oncology, Cancer Institute and Cancer Hospital, \\ Chinese Academy of Medical Sciences, Beijing 100034, P.R. China
}

Received June 1,2016; Accepted April 7, 2017

DOI: $10.3892 / \mathrm{mmr} .2017 .6879$

\begin{abstract}
Malignant cancer is one of the most serious diseases threatening the health of human beings. Natural plant alkaloids exhibit multiple biological functions, including inhibition of cell proliferation, and may have potential anticancer activity. However, most natural alkaloids may not be suitable for human therapies owing to instability, poor dissolubility and potential side effects. To improve their anticancer activity and drug effect, the present study aimed to develop new alkaloid derivatives, the phenanthroindolizidine alkaloid compounds, and evaluated their potential antitumor effects on human cancer cells in vitro. Among the several newly synthesized analogues of phenanthroindolizidine alkaloids (PAs), the compounds YS306 and YS206 exhibited an increased growth inhibition activity on HepG2 liver cancer cells and on HCT116 and HT29 colon cancer cells, with half-maximal inhibitory concentrations in the micromolar range. YS206 and YS306 $(5 \mu \mathrm{g} / \mathrm{ml})$ both significantly induced cell cycle arrest at the G2/M phase and notably decreased cell distribution at the G0/G1 and $\mathrm{S}$ phase. In addition, these two molecules significantly inhibited cancer cell migration, as analyzed by the wound-healing and Transwell assays. However, neither YS306 nor YS206 exhibited observable effects on apoptosis. Therefore, chemical structure modifications of natural PAs based on anticancer activity assessments may be feasible in the development of new cancer chemotherapeutic agents.
\end{abstract}

Correspondence to: Professor Shufang Liang, Cancer Center, West China Hospital, Sichuan University and Collaborative Innovation Center for Biotherapy, 17 Section 3, People's South Road, Chengdu, Sichuan 610041, P.R. China

E-mail: zizi2006@scu.edu.cn

Key words: phenanthroindolizidine alkaloid, anticancer, cell cycle, cell migration

\section{Introduction}

Cancer is one of the most serious diseases in the worldwide. Based on the latest data from the International Agency for Research on Cancer-World Health Organization GLOBOCAN Project 2012, there were 14.1 million cancer cases and 8.2 million cancer-related mortalities in 2012 (1). Data from the National Cancer Center Registry of China indicated that there were $\sim 4,292,000$ new cancer cases and $\sim 2,814,000$ cancer-related deaths in China in 2015 (2). A number of small chemical molecules have been reported to target cancer cell growth and cell signaling and exhibit good inhibition of tumor activity, which may potentially be further developed to antitumor drugs (3).

Alkaloids are a type of alkaline organic compounds that contain nitrogen and mostly occur in plants. Most alkaloids have complex circular structures with heterocyclic nitrogen, including indole, pyridine, quinoline and purine (4). Phenanthroindolizidine alkaloids (PAs) have been isolated from various natural plants, mainly from genera in the Asclepiadoideae family, such as Tylophora, Vincetoxicum, Pergularia and Cynanchum (5). Alkaloids have certain biological functions, including cytotoxicity, antibacterial and antiviral, and effect biochemical processes in plant and animal cells $(6,7)$. The biological function of PAs primarily includes the mutagenicity, cytotoxicity and cell biochemical processes. A previous report indicated that the drawbacks of PAs include a low water solubility and central nervous toxicity. Antofine, a representative PA, has been used as a cytotoxicity agent that has low $\mathrm{IC}_{50}$ values in the nanomolar range in multidrug-resistant and drug-sensitive cancer cells (8).

Alkaloids extracted from plants exhibit potential antitumor activity. However, most natural alkaloids are not useful for humans owing to their poor stability and dissolubility, and the potential adverse side effects. The present study aimed to develop new derivatives of PAs to improve their specific anticancer activities and cellular pharmaceutical effects on human cancer cells. 


\section{Materials and methods}

Chemical synthesis. The 12 different PA analogues were synthesized primarily based on previous reports (9). The 12 PA analogues contain the same phenanthrene ring with different functional groups at different positions. Benzoic acid with different substituents were added in a certain proportion for reaction with benzaldehyde derivatives with different substituents, and finally 12 compounds were synthesized through a series of organic chemistry experiments, including aldol condensation, esterification, $\mathrm{n}$-cyclohexylmaleimide of free radicals, reduction reaction and amination reaction. The chemical compounds were named S306, S307, S308, S206, S207, S208, S106b, XS1, XS2, XS4, XS5 and S108, and their respective hydrochloride forms were correspondingly named as YS306, YS307, YS308, YS206, YS207, YS208, YS106b, YXS1, YXS2, YXS4, YXS5 and YS108. Representative structures of two compounds, S206 and S306, are shown in Fig. 1.

The purity of all PAs used in cell experiments was up to $99 \%$, as measured by high performance liquid chromatography. The anticancer drug paclitaxel (Nanjing Kangmanlin Chemical Co., Ltd., Nanjing, China) was used as a positive control when detecting the anticancer activities of PAs. All PA compounds and paclitaxelwere dissolved in $100 \%$ DMSO to make a stock solution, and the final concentration of DMSO was adjusted to $<0.1 \%$ with Dulbecco's Modified Eagle's Medium (DMEM). All chemical compounds were firstly dissolved in $100 \%$ DMSO, and then were diluted to $5 \mathrm{mg} / \mathrm{ml}$ stock liquor with DMEM media. Finally, the stock liquor was further diluted to $0.5,5$ and $50 \mu \mathrm{g} / \mathrm{ml}$ with DMEM for subsequent in vitro tests. All the chemical solutions were stored at $4^{\circ} \mathrm{C}$, and operations were completed in a Class II biological safety cabinet (NuAire, Inc., Plymouth, MN, USA). The hydrochloride compounds had a higher solubility than their respective free auxin. Therefore, the following cellular experiments were performed using the hydrochloride compounds.

Cell culture. Human lung cancer A549 cells, liver cancer HepG2 cells and human colon cancer HT29 and HCT116 cells were purchased from American Type Culture Collection (Manassas, VA, USA), and normal human liver cell line LO2 was purchased from Cell Bank of Shanghai Institute of Cell Biology, Chinese Academy of Sciences (Shanghai, China) (10). Cells were maintained in DMEM (Gibco; Thermo Fisher Scientific, Inc., Waltham, MA, USA) supplemented with $10 \%$ fetal bovine serum (FBS; Gibco; Thermo Fisher Scientific, Inc.) at $37^{\circ} \mathrm{C}$ in humidified atmosphere with $5 \%(\mathrm{v} / \mathrm{v}) \mathrm{CO}_{2}$ and 95\% (v/v) air (10).

MTT assay. Cell proliferation was measured by the MTT assay, which was performed to rapidly detect the growth-inhibitory effects of the chemical compounds on various human cancer cells in vitro. Exponentially growing cells along with $200 \mu 1$ culture medium were seeded $(8,000$ cells/well) into a 96 -well plate. Different concentrations of the PAs $(1,2,5,10,20,30,40$ and $50 \mu \mathrm{g} / \mathrm{ml}$ ) dissolved in $100 \mu \mathrm{l}$ medium was added to each well and the plates were incubated for $48 \mathrm{~h} ; 100 \mu \mathrm{l}$ culture medium with $0.01 \%$ DMSO was used as a blank control group. Following incubation, $10 \mu \mathrm{l}$ MTT solution was added to each well and incubated for $4 \mathrm{~h}$, and the absorbance at $570 \mathrm{~nm}$ was measured to calculate the average inhibition rate. Each concentration gradient of PAs was detected at least 3 times for each cell line. The average inhibition rate was calculated according to the ratio of the blank group vs. the test group.

Double staining for apoptosis. A double staining assay (Apoptosis Detection kit; Nanjing KeyGen Biotech Co., Ltd., Nanjing, China) was used, according to the manufacturer's protocol, to assess whether the detected compounds were able to induce cell apoptosis. Exponentially growing cells were seeded $\left(3 \times 10^{5}\right.$ cells/well) in a 6 -well plate, which was incubated with different compounds for $24 \mathrm{~h}$ at $37^{\circ} \mathrm{C}$. Cells were collected, washed twice with phosphate buffered saline (PBS), and suspended in $500 \mu \mathrm{l}$ binding buffer. Cells were stained and incubated with $5 \mu 1$ Annexin V-fluorescein isothiocyanate and $2 \mu \mathrm{l}$ propidium iodide (PI) solution homogeneously for 5-15 min in the dark at room temperature. Cell suspensions were immediately measured by flow cytometry and Novoexpress version 1.0.2 software (ACEA Biosciences Inc., San Diego, CA, USA). All experiments for apoptosis were repeated 3 times.

Cell cycle analysis. Cell cycle was analyzed with the KeyGenDNA Content Quantitation Assay (Nanjing KeyGen Biotech Co., Ltd.), following the manufacturer's protocol. A total of $3 \times 10^{5}$ cells were seeded into a well of a 6 -well plate and incubated with test chemicals or $0.01 \%$ DMSO as a negative control for $24 \mathrm{~h}$. Following incubation, cells were collected, washed twice with PBS and $1 \times 10^{6}$ cells $/ \mathrm{ml}$ were fixed with $500 \mu 170 \%$ cold methanol at $4^{\circ} \mathrm{C}$ overnight. Cells were then washed with PBS, $100 \mu 1$ RNase solution was added and the plate was incubated at $37^{\circ} \mathrm{C}$ for $30 \mathrm{~min}$. Cells were stained with $400 \mu \mathrm{l} \mathrm{PI}$ at $4^{\circ} \mathrm{C}$ in the dark for $30 \mathrm{~min}$, and fluorescence intensity was analyzed by flow cytometry at $488 \mathrm{~nm}$ and using Novoexpress version 1.0.2 software (ACEA Biosciences Inc.). All experiments for cell cycle detection were repeated 3 times.

Wound-healing assay. To further assess the effects of chemical compounds on directional cell migration in vitro, a wound-healing assay was used as previously described (11). Briefly, $3 \times 10^{5}$ cells were cultured in each well for a 6 -well plate for $24 \mathrm{~h}$ at $37^{\circ} \mathrm{C}$ and then a straight scratch was made using a pipette tip on the confluent cell monolayer. Fresh media was added to remove the floating cells, and the remaining cells were imaged immediately (at $0 \mathrm{~h}$ ) using an inverted microscope and cellSens version 1.12 (model CKX31; Olympus Corporation, Tokyo, Japan). The media was removed and replaced with fresh media containing different test compounds, except for the control. Following $24 \mathrm{~h}$ incubation at $37^{\circ} \mathrm{C}$, images were captured and cell migration ability was calculated as a percentage of the area covered by cells at $24 \mathrm{~h}$ compared to the same wound area at $0 \mathrm{~h}$. Experiments were repeated 3 times.

Transwell migration assay. Cell migration was examined by a Transwell chamber apparatus (Millipore; Merck KGaA, Darmstadt, Germany), as previously described (10). Briefly, the lower chamber was filled with $800 \mu$ l DMEM containing $10 \%$ FBS. A total of $1 \times 10^{4}$ cells in $200 \mu$ l serum-free DMEM were seeded in the upper well and were respectively incubated with $1 \mu \mathrm{g} / \mathrm{ml} \mathrm{YS} 206$ and YS306 for $24 \mathrm{~h}$ at $37^{\circ} \mathrm{C}$. As a negative 

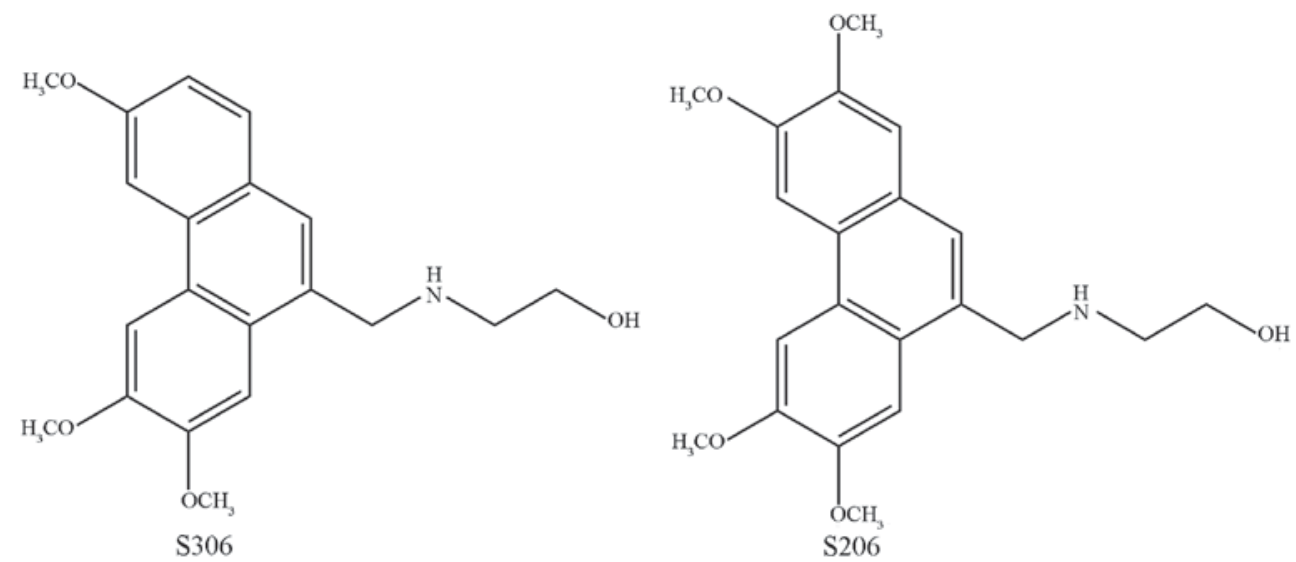

Figure 1. Chemical structure of the phenanthroindolizidine alkaloid-derived compounds S306 and S206.

control, 0.01\% DMSO was used. Migrated cells were fixed with methanol and stained with $1 \%$ crystal violet. Images were captured using an inverted microscope and cellSens version 1.12 (model, CKX31; Olympus Corporation) and the migrated cells were counted manually. The number of migratory cells in the compound-treated groups was calculated as a percentage of the control, and experiments were repeated 3 times.

\section{Results}

PAs inhibit cancer cell proliferation. To quickly screen for inhibitory effects of PAs, cancer cells were incubated with the compound for $24 \mathrm{~h}$ the status of cell growth was observed. No inhibitory effect on cell growth was observed using 0.5 or $5 \mu \mathrm{g} / \mathrm{ml}$ PA for HepG2, HCT116 or HT29 cells (data not shown). When incubated with $50 \mu \mathrm{g} / \mathrm{ml}$ PAs, increased cell growth inhibition was noted for each of these three cancer cell lines. A total of 6 out of the 12 PA analogues analyzed, including YS206, YS207, YS208, YS306, YS307 and YS308, exhibited in vitro anticancer activity (Fig. 2A). From the primary experimental results, it was clear that $50 \mu \mathrm{g} / \mathrm{ml} \mathrm{PA}$ compounds exhibited the most effective anticancer activity on HepG2, HCT116 and HT29 cells (Fig. 2A), whereas none of the tested chemicals exhibited anticancer effects on A549 cells.

Among the six PA compounds, YS206 and YS306 exhibited the most efficient growth inhibition effects on colon and liver cancer cells. Dose-response histograms for YS206 and YS306, at concentrations of between 1 and $50 \mu \mathrm{g} / \mathrm{ml}$, on HepG2, HCT116 and HT29 cells suggested that their biological effects may be concentration dependent (Fig. 2B and C). The average half-maximal inhibitory concentration $\left(\mathrm{IC}_{50}\right)$ value of the YS206 against HepG2, HCT116 and HT29 cells were $10.26,9.528$ and $8.15 \mu \mathrm{g} / \mathrm{ml}$, respectively. The $\mathrm{IC}_{50}$ of YS306 on these cells was $6.826,8.483$ and $12.35 \mu \mathrm{g} / \mathrm{ml}$, respectively. Compared with the $\mathrm{IC}_{50}$ of paclitaxel for HepG2, HCT116 and HT29 cells (3.26, 1.89 and $1.91 \mu \mathrm{g} / \mathrm{ml}$, respectively; Fig. 2D), the in vitro antitumor activity of YS206 and YS306 were slightly lower than paclitaxel. The compound YS206 appeared to exhibit a stronger growth inhibition against the colon cancer HCT116 and HT29 cells compared with YS306 on the same cells, whereas YS306 appeared to have a more effective inhibitory effect on HepG2 liver cancer cells.
The cytotoxicity of YS206 and YS306 was examined on LO2 normal liver cells and HepG2 cells. HepG2 cells appeared to be more sensitive to the treatment with $50 \mu \mathrm{g} / \mathrm{ml}$ YS206 and YS306 compared with LO2 cells (Fig. 3). The cell proliferation rate was 72.76 and $50.68 \%$ for HepG2 cells incubated with YS206 and YS306, respectively, whereas LO2 cells exhibited $\sim 80 \%$ proliferation rate when incubated with either compound (Fig. 3). These results indicated that compounds YS206 and YS306, particularly YS306, may target liver cancer cells with lower cytotoxicity for normal liver cells.

Based on these primarily experiments with several cancer cell lines, the potential biological effects of YS206 were further examined on the colon cancer HCT116 and HT29 cells, and the effects of YS306 were further investigated on HepG2 liver cancer cells.

YS206 and YS306 induce cell cycle arrest at G2/M phase. To investigate whether compounds YS206 and YS306 inhibit cell proliferation by regulating cell cycle progression, changes to the cell cycle were detected following chemical treatment for $24 \mathrm{~h}$ by PI staining and flow cytometry analysis. YS206 and YS306 $(5 \mu \mathrm{g} / \mathrm{ml})$ both significantly induced cell cycle arrest at $\mathrm{G} 2 / \mathrm{M}$ phase $(\mathrm{P}<0.01$; Fig. 4$)$, and the distribution of cells in G0/G1 and S phases were notably decreased compared with the control cells. In the HepG2 cells treated with YS306 $(5 \mu \mathrm{g} / \mathrm{ml})$ the percentage of cells at G2-M increased to $45.98 \%$, which was twice that of the control group (22.92\%; Fig. 4A). Compared with the untreated control, in which 42.37 and $34.28 \%$ of cells were at G0-G1 and S phase, respectively, HepG2 treated with YS306 had 31.23 and $22.39 \%$ of cells at the respective phases. However, no significant differences were identified when these cells were treated with $2 \mu \mathrm{g} / \mathrm{ml}$ YS306.

Both of the colon cancer cell lines treated with YS206 (5 $\mu \mathrm{g} / \mathrm{ml})$ exhibited a significantly increased number of cells arrested at the G2-M phase (Fig. 4B and C). The percentage of HCT116 cells treated with YS206 arrested at G2-M increased 2.07 -fold, from $30.52 \%$ in the untreated cells to $63.21 \%$ (Fig. 4B). Additionally, the number of HCT116 cells at G0-G1 and $\mathrm{S}$ were respectively decreased from 43.40 and $28.83 \%$ in the control to 34.70 and $10.61 \%$ with $5 \mu \mathrm{g} / \mathrm{ml}$ YS206. Similar results were observed in HT29 cells incubated with $5 \mu \mathrm{g} / \mathrm{ml}$ YS206 (Fig. 4C). However, no significant differences were identified in either HCT116 or HT29 cells treated with $2 \mu \mathrm{g} / \mathrm{ml}$ of YS306. 


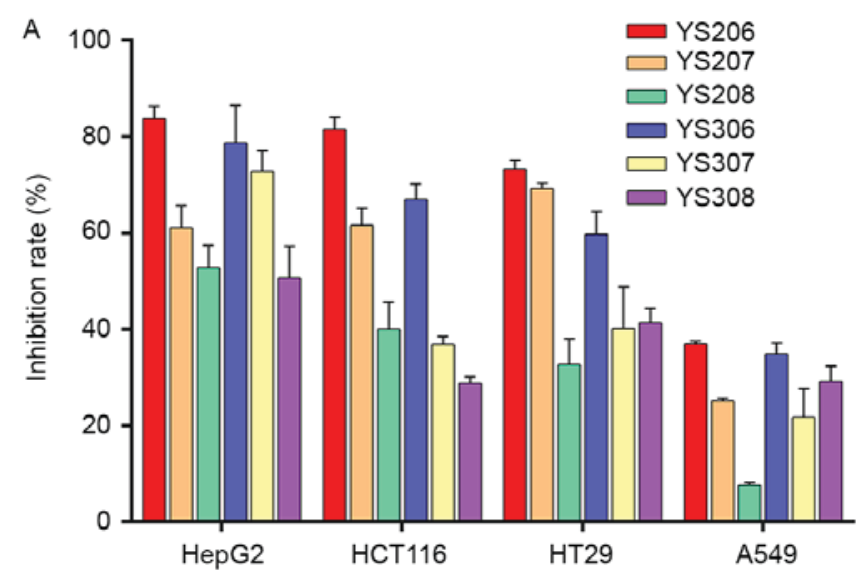

B
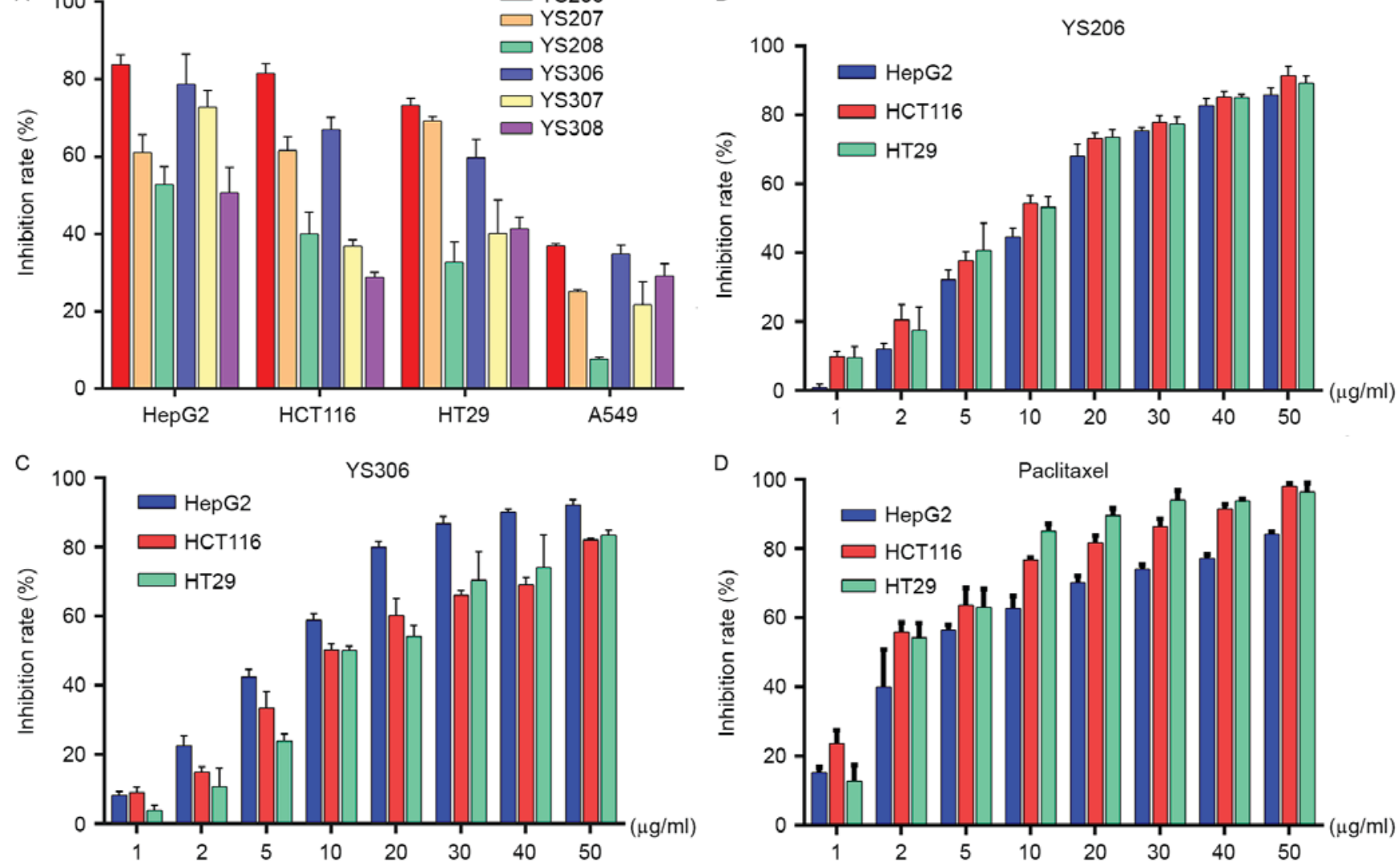

Figure 2. Cell growth inhibitory activities of 6 PA-derived compounds against human cancer cells in vitro. (A) Cell growth inhibition of HepG2 liver cancer, HCT116 and HT29 colon cancer, and A549 lung cancer cells treated with $50 \mu \mathrm{g} / \mathrm{ml}$ PA compounds YS206, YS207, YS208, YS306, YS307 and YS308 (B-D) Various concentrations (1-50 $\mu \mathrm{g} / \mathrm{ml})$ of YS206, YS306 and the anticancer drug paclitaxel were used to treat HepG2, HCT116 and HT29 cells and growth inhibition was examined. PA, phenanthroindolizidine alkaloid.

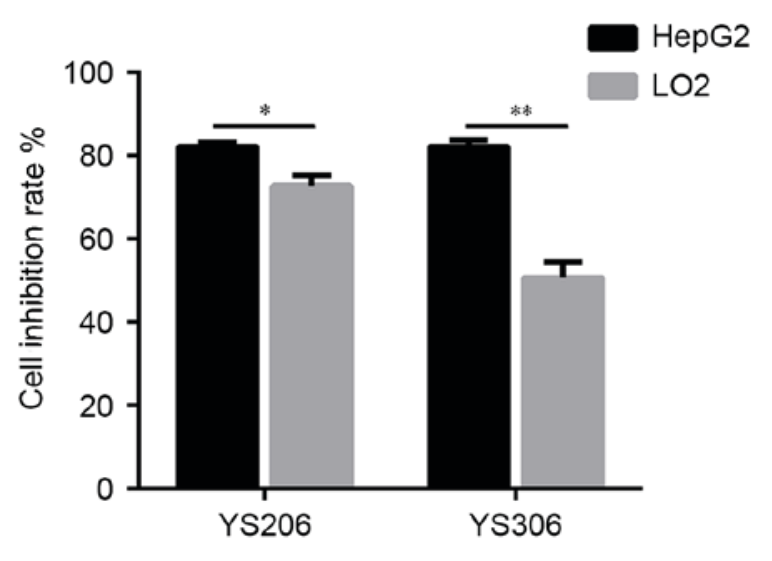

Figure 3. Cell proliferation was compared between LO2 normal liver cells and HepG2 liver cancer cells following treatment with $50 \mu \mathrm{g} / \mathrm{ml}$ YS206 or YS306 for 24 h. ${ }^{*} \mathrm{P}<0.05 ;{ }^{* *} \mathrm{P}<0.01$.

YS306 and YS206 inhibit cell migration. The effects of YS306 and YS206 on cell migration were also examined. YS306 $(1-2 \mu \mathrm{g} / \mathrm{ml})$ significantly inhibited HepG2 cell migration Fig. 5) and YS206 $(1-2 \mu \mathrm{g} / \mathrm{ml})$ greatly reduced colon cancer migration in vitro (Figs. 6 and 7). In the scratch wound-healing assay, the wound closure rate of HepG2 cells was notably decreased when treated with $1 \mu \mathrm{g} / \mathrm{ml}(26.2 \%)$ or $2 \mu \mathrm{g} / \mathrm{ml}$ (15.0\%) compared with untreated control HepG2 cells (63.2\%; $\mathrm{P}<0.001$; Fig. 5A). Similar reductions in migration ability were observed using the Transwell assay (Fig. 5B), in which the number of migrating cells was reduced to 63.6 and $43.1 \%$ with

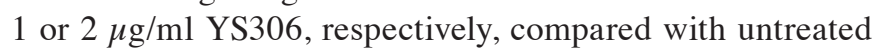
control group ( $\mathrm{n}=3$; $\mathrm{P}<0.01$; Fig. $5 \mathrm{~B})$.

YS206 exhibited similar inhibitory effects on cell migration of HCT116 and HT29 cells. For HCT116 cells, the wound closure rate was about 27.5 and $16.9 \%$ with 1 or $2 \mu \mathrm{g} / \mathrm{ml} \mathrm{YS206}$ treatment, compared with $59.7 \%$ coverage in the control cells (Fig. 6A). In the Transwell assay, compared with the untreated control group, cell migration was decreased to $64.7,38.4 \%$ in response to $1,2 \mu \mathrm{g} / \mathrm{ml}$ YS206 treatment $(\mu \mathrm{g} / \mathrm{ml})(\mathrm{n}=3$; $\mathrm{P}<0.001$; Fig. 6B). For HT29 cells, the wound closure rates were 30.2 and $15.6 \%$ when treated with 1 or $2 \mu \mathrm{g} / \mathrm{ml} \mathrm{YS206,}$ compared with the $68.3 \%$ coverage in the untreated control (Fig. 7A). Transwell assay analysis revealed that HT29 cells treated with 1 or $2 \mu \mathrm{g} / \mathrm{ml}$ YS206 exhibited 61.5 and $35.4 \%$ cell migration compared with cells in the untreated control group $(\mathrm{n}=3 ; \mathrm{P}<0.001 ;$ Fig. 7B).

YS306 and YS206 have no effects on cell apoptosis. The effects of YS306 and YS206 on cell apoptosis were examined by Annexin V-FITC/PI staining and flow cytometry. HepG2

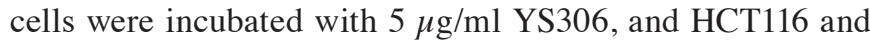
HT29 cells were incubated with 2 or $5 \mu \mathrm{g} / \mathrm{ml}$ YS206. Cancer cells were also incubated with $0.01 \%$ DMSO as a negative control. However, no significant differences in the levels of cell apoptosis were identified for any of the PA treatments (Fig. 8). 

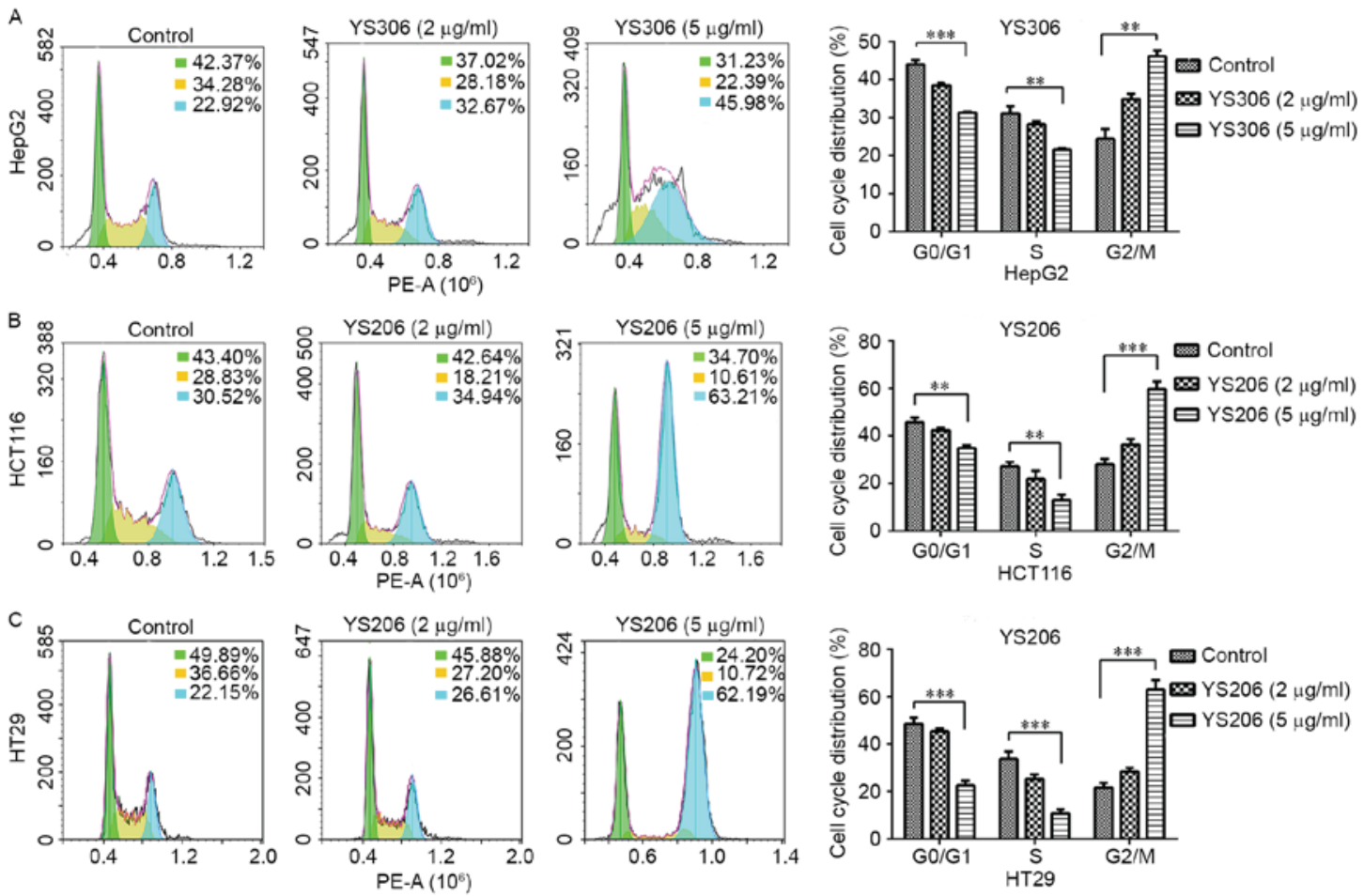

Figure 4. Cell cycle arrest and distribution were induced by YS306 and YS206 in cancer cells in vitro. (A) Cell cycle was changed in HepG2 cells treated with $5 \mu \mathrm{g} / \mathrm{ml}$ YS306 for $24 \mathrm{~h}$ compared with untreated control cells. Similar results were observed for (B) HCT116 and (C) HT29 cells treated with 2 or $5 \mu \mathrm{g} / \mathrm{ml}$ YS206 for 24 h. ${ }^{* *} \mathrm{P}<0.01 ;{ }^{* * *} \mathrm{P}<0.001$.

A

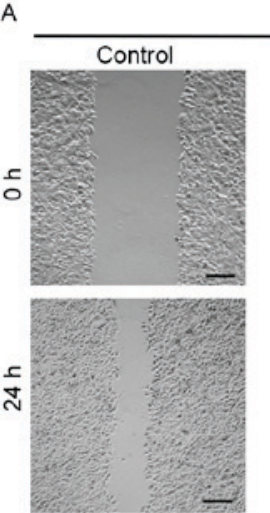

B
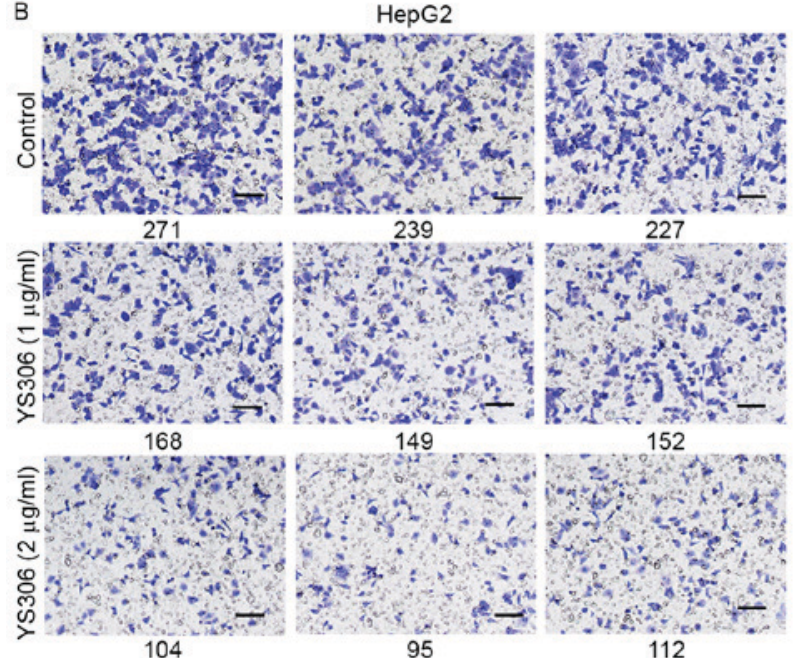

HepG2
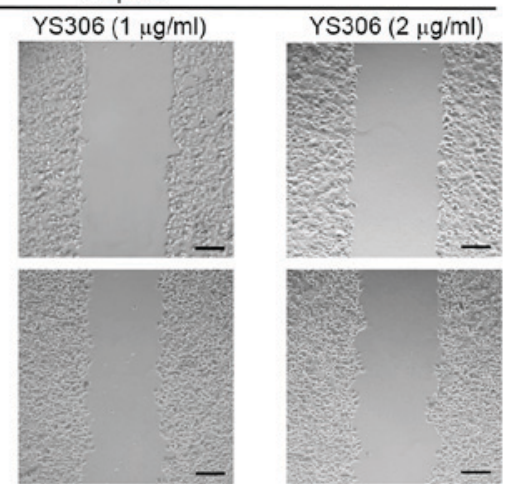

HepG2

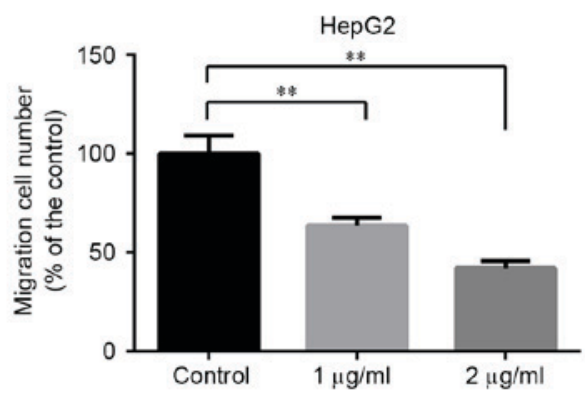

Figure 5. Compound YS306 inhibits HepG2 liver cancer cell migration in wound-healing and Transwell assays. (A) Cell migrationwas detected by wound-healing assay. Images were captured at 0 and $24 \mathrm{~h}$ incubation with YS306, and the percent of migration was measured. (B) In the Transwell migration assay, cells were stained with crystal violet and counted manually (the number below each image). Scale bar, $100 \mu \mathrm{m} ;{ }^{* * *} \mathrm{P}<0.01$ and ${ }^{* * *} \mathrm{P}<0.001$ vs. Control. 
A
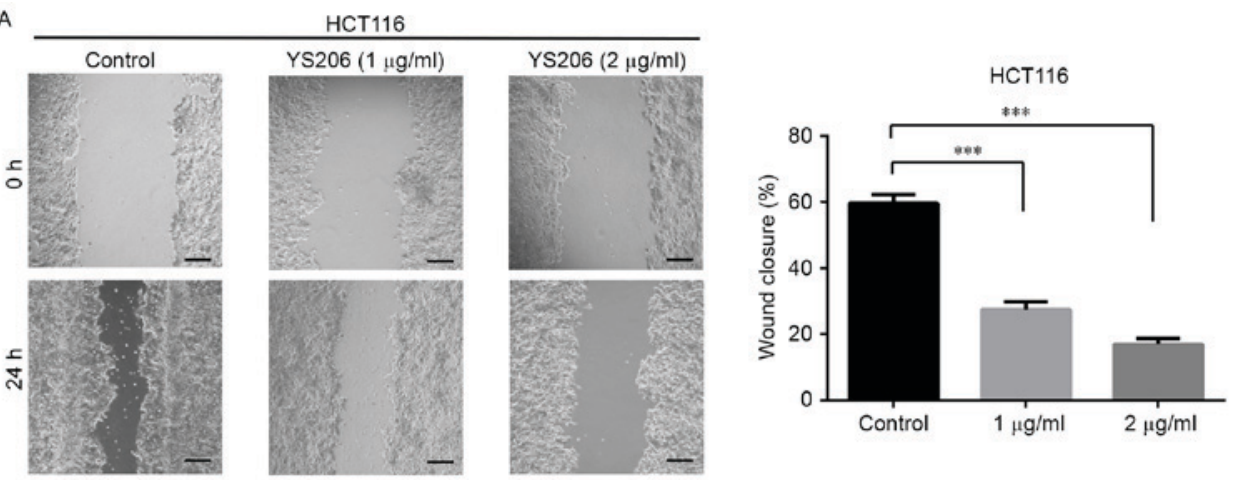

HCT116
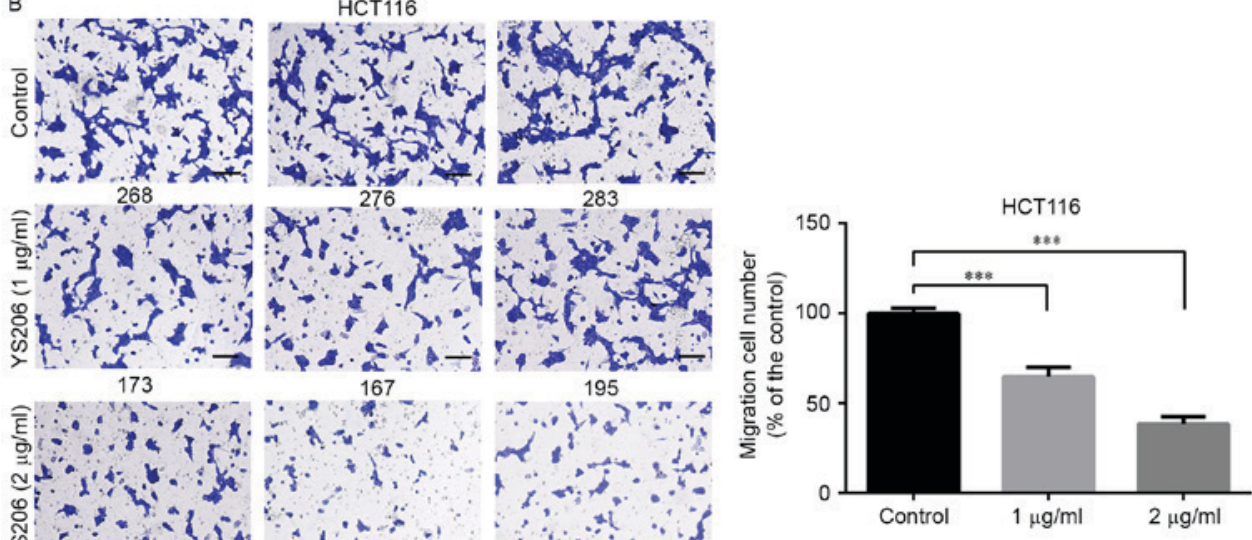

Figure 6. Compound YS206 inhibits HCT116 colon cancer cell migration in wound-healing and Transwell assays. (A) In the wound-healing assay, HCT116 cells were treated with 1 or $2 \mu \mathrm{g} / \mathrm{ml}$ YS206, and images were captured at 0 and $24 \mathrm{~h}$. (B) In the Transwell migration assay, cells were stained with crystal violet and counted manually (the number below each image). Scale bar, $100 \mu \mathrm{m} ;{ }^{* * * *} \mathrm{P}<0.001 \mathrm{vs}$. control.

A

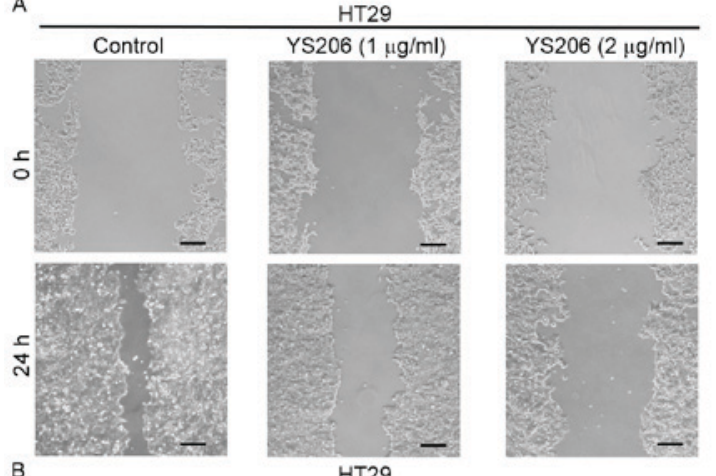

B

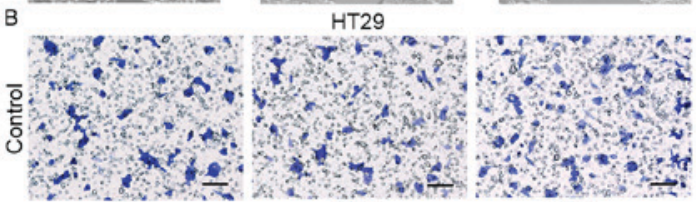

226

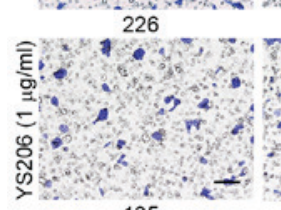

135

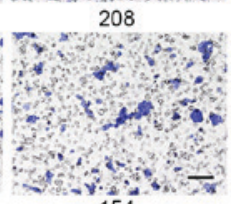

154 246

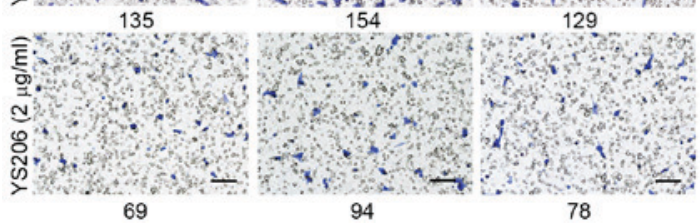

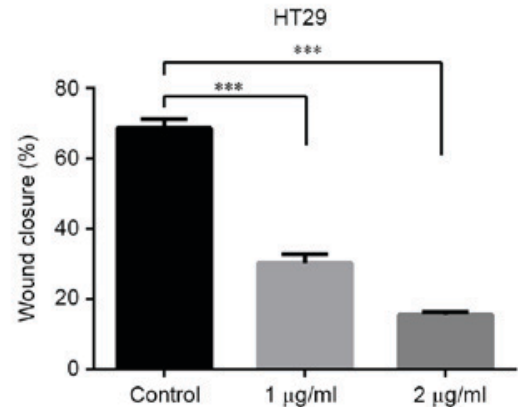

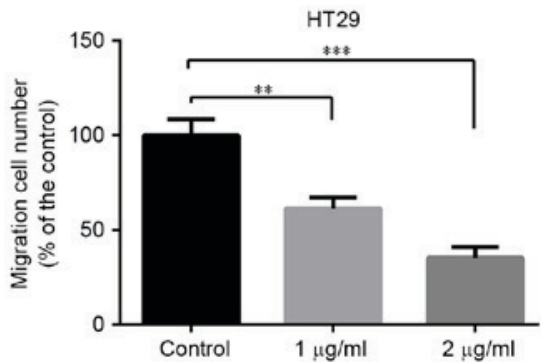

Figure 7. Compound YS206 inhibits HT29 colon cancer cell migration in wound-healing and Transwell migration assays. (A) HT29 cells were treated with 1 or $2 \mu \mathrm{g} / \mathrm{ml} \mathrm{YS} 206$, and images were captured at 0 and $24 \mathrm{~h}$ in the wound-healing assay. (B) Cells in the Transwell migration assay were stained with crystal violet and counted manually (the number below each image). Scale bar, $100 \mu \mathrm{m} ;{ }^{* *} \mathrm{P}<0.01$ and ${ }^{* * * *} \mathrm{P}<0.001 \mathrm{vs}$. control. 

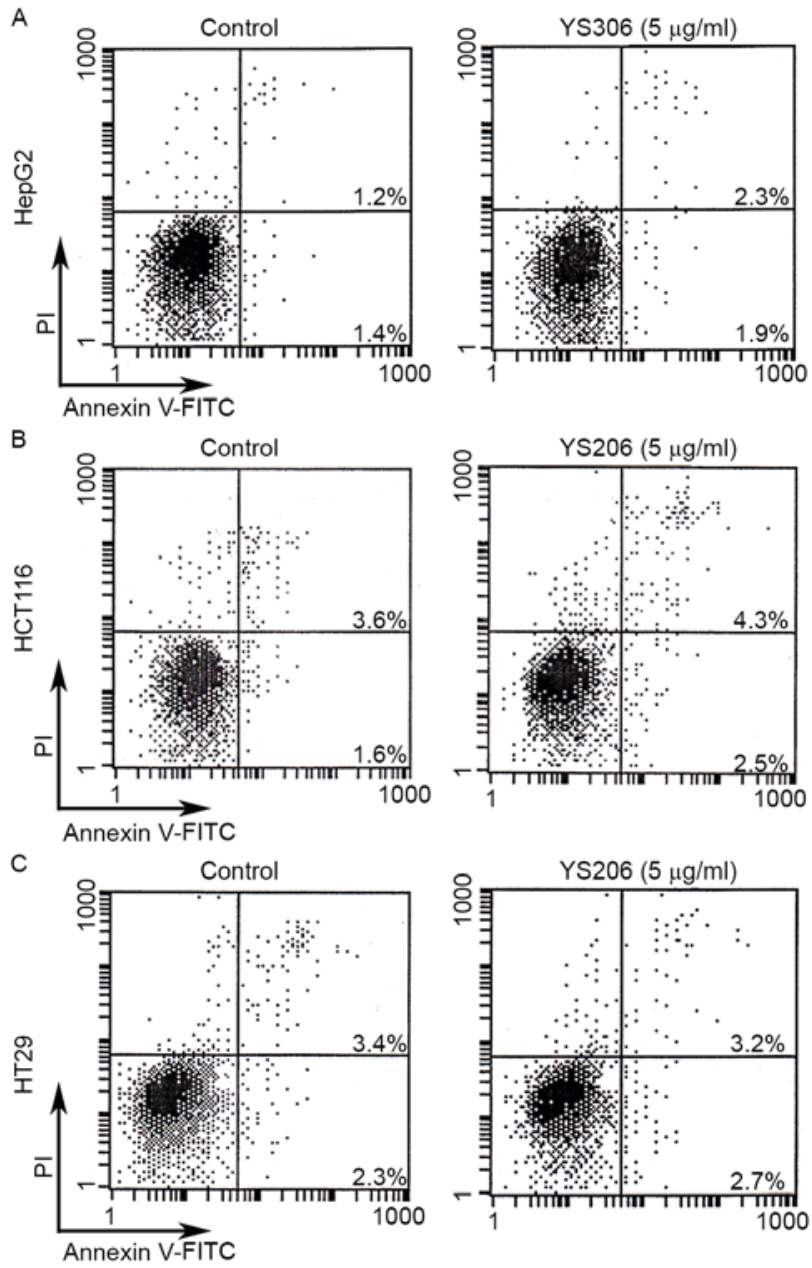

Figure 8. Compounds YS306 and YS206 exhibit no effects on cell apoptosis (A) HepG2 liver cancer cells and (B) HCT116 and (C) HT29 colon cancer cells were treated with $5 \mu \mathrm{g} / \mathrm{ml}$ YS306 or YS206 for $24 \mathrm{~h}$, collected and incubated with Annexin V-FITC/PI for $20 \mathrm{~min}$ at room temperature, then immediately analyzed by flow cytometry. FITC, fluorescein isothiocyanate; PI, propidium iodide.

\section{Discussion}

Over the past ten years, there has been rapid development of organic synthesis technologies, and subsequently, an increasing number of alkaloids have been synthesized, which provides more choices for clinical therapy and experimental antitumor research (12). These naturally occurring products and compound derivatives have exhibited great efficacy as antiviral, antibacterial and antitumor treatments (13).

The anti-proliferation activity in different cancer cells is usually the first effect to be examined when evaluating potential new antitumor agents. The $\mathrm{IC}_{50}$ values of the compounds synthesized by the present study were mainly at a level of micromolar concentration, and among them, YS206 and YS306 were selected for further analysis. Compared with the anticancer drug paclitaxel, these two compounds exhibited potential growth inhibition effects on HepG2, HCT116 and HT29 cells with relatively low toxicity on normal cells. For compound YS306, the average inhibition rate for HepG2 cells was higher than for LO2 human normal liver cells, by 1.6-fold, suggesting that YS306 may have specificity in inhibiting liver cancer cell growth. In addition, YS306 exhibited greater anti-proliferation effects on HepG2 liver cancer cells compared with HCT116 and HT29 colon cancer cells. It was noticed that the only difference between compounds S306 and S206 is one ethoxyethyl at the 1' position (Fig. 1), which may contribute to the difference in cell preference of these two chemical molecules. Two other, similar compounds within these series, YS307 and YS207 were slightly inferior in solubility than YS306 and YS206, which leads to poor cell inhibition activity. In future studies, these PA compounds may be modified to improve their anticancer activity in vitro, and nude mouse xenografts may then be performed to explore their effects in suppressing cancer cell growth and metastasis in vivo.

Previous studies have indicated that PAs inhibit cell proliferation through many different mechanisms, including inhibition of protein and DNA synthesis, induction of cell apoptosis and suppression of dihydrofolate reductase activity (14-16). Additional studies have demonstrated that PAs may also enhance cytotoxic effects and inhibit cell migration and metastasis of cancer cells $(17,18)$. To investigate the cell biological effects induced by YS206 and YS306 treatment, cell cycle distribution, cell migration and cell apoptosis were analyzed in the three cancer cell lines aforementioned. HepG2, HCT116 and HT29 cells treated with YS206 or YS306 exhibited reduced proliferation, significant changes to the cell cycle and suppressed cell migration. The low concentration of $5 \mu \mathrm{g} / \mathrm{ml}$ YS206 and YS306 was able to induce cell cycle arrest at $\mathrm{G} 2 / \mathrm{M}$ phase. Compared with normal cells, cancer cells are characteristically sufficient in stimulating their own growth, which results in abnormal proliferation through the dysregulation of their cycle progression and fission activities (19). G1/S and $\mathrm{G} 2 / \mathrm{M}$ are the most complex stages of the cell cycle, which are influenced by environmental conditions (20). Therefore, the development of new drugs to suppress tumor growth should target these two cell stages.

Pinosylvin is a naturally occurring trans-stilbenoid that mainly occurs in Pinus species (21), which has been revealed to regulate the cell cycle by through the cyclin-dependent kinase complex $(20,22)$. The novel triterpenoid 25-methoxyhispidol, extracted from Poncirustrifoliata, was demonstrated to exhibit growth inhibition activity against cancer cells, with cell cycle arrested at G0/G1 phase (23). Antofine is a naturally occurring PA found in Cynanchum paniculatum, from which some analogues and derivatives have also been reported to regulate the cell cycle at G0-G1 phase (24). In the present study, $5 \mu \mathrm{g} / \mathrm{ml}$ YS306 and YS206 significantly induced cell cycle arrest at G2/M phase in HepG2, HCT116 and HT29 cells; cell distribution in G0/G1 and S phases were notably decreased compared with Control cells, and the effect was more significant than using $2 \mu \mathrm{g} / \mathrm{ml}$ YS306 and YS206. The present results are similar to a previous report on human colon cancer $\mathrm{Col} 2$ cells that were induced by another natural antofine that was isolated from Cynanchum paniculatum (25). Moreover, vinblastine and vincristine, which are extracts from Catharanthusroseus, were demonstrated to affect the G2/M phase to inhibit microtubule assembly (26).

In addition to acting on cell cycle, YS306 and YS206 significantly inhibited cell migration in HepG2, HCT116 and HT29 cells. Cell migration in vitro, or cell metastasis in vivo, is one of the fundamental features of malignant tumors, which is one primary cause of mortality in patients with cancer (27). YS306 
and YS206 may be promising compounds for targeting cancer cell metastasis; however, neither compound exhibited effects on cell apoptosis, as determined by flow cytometric analysis following $5 \mu \mathrm{g} / \mathrm{ml}$ YS306 or YS206 treatment in HepG2, HCT116 and HT29 cells. These results were similar to previous reports on the PA antofine and tylophorine (24,28), which demonstrated that the distribution of sub-G1 phase was not notably altered, and that cell growth inhibition of human lung cancer A549 cells by derivatives of antofine is not due to cell apoptosis.

Considering the chemical structures of YS306 and YS206, the biggest difference in their structure is the side chain compared with the classical PA antofine. In the present study, the lateral heterocyclic nitrogen was opened and the number of side element carbons were decreased at the same time, which brought about a change in polarity. Compounds with increased polarity have been indicated to possess good anticancer activity, and the methoxyl group in different positions of the phenanthrene ring may be another reason for anticancer abilities (29-31). In addition, a previous report revealed that water solubility may be a limitation in clinical use (28). In the present study, YS206 and YS306 had better water solubility than the other 10 PAs, which may be why the two compounds have more effective anti-cancer activity than other derivatives.

A number of previous studies have indicated that PAs may inhibit cancer cell proliferation through different molecular mechanisms, including inhibition of protein and DNA synthesis, suppression of dihydrofolate reductase and induction of apoptosis through the tumor necrosis factor $\alpha$ signaling pathway $(14,15,23)$. In conclusion, the mechanisms of anti-proliferation and inhibition of cell migration of YS306 and YS206 may be relative to the suppression of related protein synthesis and cell signal transduction pathways, which needs to be analyzed in detail in future studies.

\section{Acknowledgements}

The present study was financially supported by the National Key Basic Research Program of China (grant nos. 2013CB911303 and 2011CB910703), National 863 High Tech Program (grant no. 2014AA020608), the National Natural Sciences Foundation of China (grant no. 31470810), the Science \& Technology Department of Sichuan Province (grant no. 2017JY0232), and the Health and Family Planning Commission of Sichuan Province (grant no. 17ZD045).

\section{References}

1. Torre LA, Bray F, Siegel RL, Ferlay J, Lortet-Tieulent J and Jemal A: Global cancer statistics, 2012. CA Cancer J Clin 65: 87-108, 2015.

2. Chen W, Zheng R, Baade PD, Zhang S, Zeng H, Bray F, Jemal A, Yu XQ and He J: Cancer statistics in China, 2015. CA Cancer J Clin 66: 115-132, 2016.

3. Newman DJ and Cragg GM: Natural products as sources of new drugs over the 30 years from 1981 to 2010. J Nat Prod 75: 311-335, 2012.

4. Cushnie TT, Cushnie B and Lamb AJ: Alkaloids: An overview of their antibacterial, antibiotic-enhancing and antivirulence activities. Int J Antimicrob Agents 44: 377-386, 2014.

5. Saraswati S, Kanaujia PK, Kumar S, Kumar R and Alhaider AA: Tylophorine, a phenanthraindolizidine alkaloid isolated from Tylophora indica exerts antiangiogenic and antitumor activity by targeting vascular endothelial growth factor receptor 2-mediated angiogenesis. Mol Cancer 12: 82, 2013.
6. Ibrahim SR and Mohamed GA: Marine pyridoacridine alkaloids: Biosynthesis and biological activities. Chem Biodivers 13: 37-47, 2016.

7. Ansha $\mathrm{C}$ and Mensah $\mathrm{K}$ : A review of the anticancer potential of the antimalarial herbal cryptolepis sanguinolenta and its major alkaloid cryptolepine. Ghana Med J 47: 137-147, 2014.

8. Staerk D, Lykkeberg AK, Christensen J, Budnik BA, Abe F and Jaroszewski JW: In vitro cytotoxic activity of phenanthroindolizidine alkaloids from Cynanchum vincetoxicum and Tylophora tanakae against drug-sensitive and multidrug-resistant cancer cells. J Nat Prod 65: 1299-1302, 2002.

9. Su CR, Damu AG, Chiang PC, Bastow KF, Morris-Natschke SL, Lee KH and Wu TS: Total synthesis of phenanthroindolizidine alkaloids $( \pm /-)$-antofine, $( \pm /-)$-deoxypergularinine, and their dehydro congeners and evaluation of their cytotoxic activity. Bioorg Med Chem 16: 6233-6241, 2008.

10. Jin X, Liu Y, Liu J, Lu W, Liang Z, Zhang D, Liu G, Zhu H, Xu N and Liang S: The overexpression of IQGAP1 and $\beta$-catenin is associated with tumor progression in hepatocellular carcinoma in vitro and in vivo. PLoS One 10: e0133770, 2015.

11. Zhou J, Liang S, Fang L, Chen L, Tang M, Xu Y, Fu A, Yang J and Wei Y: Quantitative proteomic analysis of HepG2 cells treated with quercetin suggests IQGAP1 involved in quercetin-induced regulation of cell proliferation and migration. OMICS 13: 93-103, 2009.

12. Shang S, Monfregola L and Caruthers MH: Peptide-substituted oligonucleotide synthesis and non-toxic, passive cell delivery. Sig Trans Target Ther: 16019, 2016.

13. Newman DJ, Cragg GM and Snader KM: Natural products as sources of new drugs over the period 1981-2002. J Nat Prod 66: 1022-1037, 2003.

14. Lv H, Ren J, Ma S, Xu S, Qu J, Liu Z, Zhou Q, Chen X and Yu S: Synthesis, biological evaluation and mechanism studies of deoxytylophorinine and its derivatives as potential anticancer agents. PLoS One 7: e30342, 2012.

15. Rao KN and Venkatachalam S: Inhibition of dihydrofolate reductase and cell growth activity by the phenanthroindolizidine alkaloids pergularinine and tylophorinidine: The in vitro cytotoxicity of these plant alkaloids and their potential as antimicrobial and anticancer agents. Toxicol In Vitro 14: 53-59, 2000.

16. Ueno S, Yamazaki R, Ikeda T, Yaegashi T and Matsuzaki T: Antitumor effect of a novel phenanthroindolizidine alkaloid derivative through inhibition of protein synthesis. Anticancer Res 34: 3391-3397, 2014.

17. Song J, Kwon Y, Kim S and Lee SK: Antitumor activity of phenanthroindolizidine alkaloids is associated with negative regulation of met endosomal signaling in renal cancer cells. Chem Biol 22: 504-515, 2015.

18. Wu TS, Su CR and Lee KH: Cytotoxic and anti-HIV phenanthroindolizidine alkaloids from Cryptocarya chinensis. Nat Prod Commun 7: 725, 2012.

19. Hanahan D and Weinberg RA: The hallmarks of cancer. Cell 100: $57-70,2000$.

20. Schwartz GK and Shah MA: Targeting the cell cycle: A new approach to cancer therapy. J Clin Oncol 23: 9408-9421, 2005.

21. Park EJ, Chung HJ, Park HJ, Kim GD, Ahn YH and Lee SK: Suppression of Src/ERK and GSK-3/ $\beta$-catenin signaling by pinosylvin inhibits the growth of human colorectal cancer cells. Food Chem Toxicol 55: 424-433, 2013.

22. Matsushime H, Quelle DE, Shurtleff SA, Shibuya M, Sherr CJ and Kato JY: D-type cyclin-dependent kinase activity in mammalian cells. Mol Cell Biol 14: 2066-2076, 1994.

23. Chung HJ, Park EJ, Pyee Y, Hua Xu G, Lee SH, Kim YS and Lee SK: 25-Methoxyhispidol A, a novel triterpenoid of Poncirus trifoliata, inhibits cell growth via the modulation of EGFR/c-Src signaling pathway in MDA-MB-231 human breast cancer cells. Food Chem Toxicol 49: 2942-2946, 2011.

24. Min HY, Chung HJ, Kim EH, Kim S, Park EJ and Lee SK: Inhibition of cell growth and potentiation of tumor necrosis factor- $\alpha$ (TNF- $\alpha$ )-induced apoptosis by a phenanthroindolizidine alkaloid antofine in human colon cancer cells. Biochem Pharmacol 80: 1356-1364, 2010.

25. Lee SK, Nam KA and Heo YH: Cytotoxic activity and G2/M cell cycle arrest mediated by antofine, a phenanthroindolizidine alkaloid isolated from Cynanchum paniculatum. Planta Med 69: 21-25, 2003.

26. Himes RH, Kersey RN, Heller-Bettinger I and Samson FE: Action of the vinca alkaloids vincristine, vinblastine, and desacetyl vinblastine amide on microtubules in vitro. Cancer Res 36: 3798-3802, 1976. 
27. Cheng GZ, Chan J, Wang Q, Zhang W, Sun CD and Wang LH: Twist transcriptionally up-regulates AKT2 in breast cancer cells leading to increased migration, invasion, and resistance to paclitaxel. Cancer Res 67: 1979-1987, 2007.

28. Kwon Y, Song J, Lee B, In J, Song H, Chung HJ, Lee SK and Kim S: Design, synthesis, and evaluation of a water-soluble antofine analogue with high antiproliferative and antitumor activity. Bioorg Med Chem 21: 1006-1017, 2013.

29. Gao W, Bussom S, Grill SP, Gullen EA, Hu YC, Huang X, Zhong S, Kaczmarek C, Gutierrez J, Francis S, et al: Structure-activity studies of phenanthroindolizidine alkaloids as potential antitumor agents. Bioorg Med Chem Lett 17: 4338-4342, 2007.
30. Wang Z, Wu M, Wang Y, Li Z, Wang L, Han G, Chen F, Liu Y, Wang K, Zhang A, et al: Synthesis and SAR studies of phenanthroindolizidine and phenanthroquinolizidine alkaloids as potent anti-tumor agents. Eur J Med Chem 51: 250-258, 2012.

31. Fu Y, Lee SK, Min HY, Lee T, Lee J, Cheng M and Kim S: Synthesis and structure-activity studies of antofine analogues as potential anticancer agents. Bioorg Med Chem Lett 17: 97-100, 2007. 